\title{
ALVEOLAR AND ARTERIAL OXYGEN TENSIONS AND THE SIG- NIFICANCE OF THE ALVEOLAR-ARTERIAL OXYGEN TENSION DIFFERENCE IN NORMAL MEN ${ }^{1}$
}

\author{
By GILES F. FILLEY, FERNAND GREGOIRE, AND GEORGE W. WRIGHT \\ (From the Department of Physiology, the Edward L. Trudeau Foundation, Saranac Lake, \\ New York)
}

(Submitted for publication November 16, 1953; accepted December 2, 1953)

We have had two objectives in determining alveolar and arterial oxygen tensions. It was hoped that they might be sensitive criteria for the normality of pulmonary oxygen transfer in health and disease. Secondly, a study of these oxygen tension values together with other respiratory measurements might further elucidate the process by which pulmonary artery blood becomes oxygenated as it perfuses the lung.

The purposes of this paper are: 1 . To examine the validity and accuracy of the methods by which alveolar $\mathrm{PO}_{2}$ is determined, the technique for estimating arterial $\mathrm{PO}_{2}$ and $\mathrm{PCO}_{2}$ having been critically discussed elsewhere (1). 2. To present the data from which the alveolar-arterial oxygen tension difference has been calculated in a group of normal men breathing atmospheric air. 3. To discuss the significance of this difference in the resting and exercise state.

\section{The Validity and Accuracy of the Method for Calculating Alveolar $P_{O_{2}}$}

The gas within the lungs is continuously fluctuating in composition and is not uniformly distributed $(2,3)$. For this reason and others of a technical nature $(4,5)$, direct sampling of alveolar gas, especially during exercise and in pathological subjects, will not disclose the true values of alveolar $\mathrm{Po}_{2}$ and $\mathrm{PCO}_{2}$. An alveolar $\mathrm{Po}_{2}$ may be calculated by means of the Bohr relation (6) and alveolar equations based on it $(7,8)$ provided that certain requirements are satisfied.

The Bohr relation can be used to calculate an alveolar $\mathrm{Po}_{2}$ when the alveolar $\mathrm{PCO}_{2}$ and the R.Q. of expired gas are known if one accepts as correct that "the R.Q. of expired and alveolar air are the same" (9). The R. Q. of expired gas can be ac-

\footnotetext{
1 These studies were aided by a contract between the Office of Naval Research, Department of the Navy, and the Trudeau Foundation (NR 112-214).
}

curately measured but if one wishes to calculate an alveolar $\mathrm{PO}_{2}$ it is still necessary to know the alveolar $\mathrm{PCO}_{2}$ during the period that the expired gas is collected. Rossier and Blickenstorfer (10). and Riley, Lilienthal, Proemmel, and Franke (11) have suggested that if one assumes that $\mathrm{CO}_{2}$ equilibrium is attained between pulmonary capillary blood and alveolar gas one can substitute the directly measured arterial $\mathrm{PCO}_{2}$ for alveolar $\mathrm{PCO}_{2}$, thus providing the remaining necessary term for calculating an alveolar $\mathrm{Po}_{2}$. Leaving the matter of whether or not the above equilibrium is always attained for later discussion, can one accept without reservation the hypothesis that the arterial $\mathrm{PCO}_{2}$ measured during any one period is truly representative of the $\mathrm{PCO}_{2}$ of the alveolar gas that contributed to the expired gas collected during the same period?

It is clear that this hypothesis is acceptable only when the ratio of the volumes of $\mathrm{CO}_{2}$ and $\mathrm{O}_{2}$ exchanged between pulmonary blood and alveolar gas and simultaneously between alveolar and expired gas is the same. In other words, when the R.Q. of the pulmonary blood phase, alveolar gas phase and expired gas phase are identical. Riley and Cournand (7) have stated "that the blood R.Q., the alveolar R. Q., and the expired air R.Q. are identical" when a "steady state" is attained. Since the calculation of an alveolar $\mathrm{Po}_{2}$ requires that these R.Q.'s be equal, it is pertinent to examine the direct evidence bearing on the satisfaction of this requirement under actual conditions of measurement and to disclose those circumstances under which the requirement may be unfulfilled.

The $\mathrm{CO}_{2}-\mathrm{O}_{2}$ exchange ratio, when determined by analysis of expired gas collected over a sufficiently long period, represents the respiratory quotient of the body as a whole. When, however, expired gas is collected for brief periods, it is desirable to designate this ratio as $\mathrm{R}$ to indicate that 
TABLE I

Typical spontaneous variations of the breathing pattern and gas exchange observed in normal subjects breathing air at rest and during exercise

\begin{tabular}{|c|c|c|c|c|c|c|c|c|c|c|c|}
\hline $\begin{array}{l}\text { Exp. } \\
\text { No. } 1^{*}\end{array}$ & \multicolumn{2}{|c|}{ Minutes.......1 } & \multirow{2}{*}{$\begin{array}{l}2 \\
6.27 \\
.237 \\
.84\end{array}$} & \multirow{2}{*}{$\begin{array}{c}3 \\
6.74 \\
.226 \\
.90 \\
\end{array}$} & \multirow{2}{*}{$\begin{array}{c}4 \\
5.09 \\
.198 \\
.79\end{array}$} & \multirow{2}{*}{$\begin{array}{c}5 \\
7.81 \\
.258 \\
.92 \\
\end{array}$} & \multirow{2}{*}{$\begin{array}{c}6 \\
7.44 \\
.232 \\
.91\end{array}$} & \multirow{2}{*}{$\begin{array}{c}7 \\
5.20 \\
.192 \\
.73\end{array}$} & \multirow{2}{*}{$\begin{array}{c}8 \\
6.18 \\
.234 \\
.74\end{array}$} & \multirow{2}{*}{$\begin{array}{l}9 \\
6.63 \\
.226 \\
.77\end{array}$} & \multirow{2}{*}{$\begin{array}{l}10 \\
5.68 \\
.213 \\
.76\end{array}$} \\
\hline Resting & $\begin{array}{l}\mathrm{MV} \\
\mathrm{O}_{2} \text { Uptake } \\
\mathbf{R}_{\mathbf{E}}\end{array}$ & $\begin{array}{l}.68 \\
.213 \\
.87\end{array}$ & & & & & & & & & \\
\hline $\begin{array}{l}\text { Exp. } \\
\text { No. } 2\end{array}$ & $\begin{array}{l}\text { Collection } \\
\text { time in sec. }\end{array}$ & $\ldots 75$ & 70 & 74 & 68 & 74 & 72 & 79 & 80 & 80 & 73 \\
\hline Resting & $\begin{array}{l}\mathrm{MV} \\
\mathrm{O}_{2} \text { Uptake } \\
\mathrm{R}_{\mathrm{E}}\end{array}$ & $\begin{array}{l}6.98 \\
.276 \\
.80 \\
\end{array}$ & $\begin{array}{l}6.48 \\
.250 \\
.79 \\
\end{array}$ & $\begin{array}{l}6.50 \\
.230 \\
.81 \\
\end{array}$ & $\begin{array}{l}6.68 \\
.228 \\
.79 \\
\end{array}$ & $\begin{array}{l}7.28 \\
.225 \\
.83 \\
\end{array}$ & $\begin{array}{l}7.08 \\
.234 \\
.83 \\
\end{array}$ & $\begin{array}{l}6.65 \\
.226 \\
.80 \\
\end{array}$ & $\begin{array}{l}6.45 \\
.234 \\
.76\end{array}$ & $\begin{array}{l}6.38 \\
.234 \\
.80\end{array}$ & $\begin{array}{l}6.80 \\
.250 \\
.77\end{array}$ \\
\hline $\begin{array}{l}\text { Exp. } \\
\text { No. } 3\end{array}$ & \multicolumn{3}{|c|}{$\begin{array}{l}\text { Collection } \\
\text { time in sec. . . . . . } 143\end{array}$} & \multicolumn{2}{|c|}{134} & \multicolumn{2}{|c|}{129} & \multicolumn{2}{|c|}{130} & \multicolumn{2}{|c|}{131} \\
\hline Resting & $\begin{array}{l}\mathrm{MV} \\
\mathrm{O}_{2} \text { Uptake } \\
\mathrm{R}_{\mathrm{E}}\end{array}$ & \multicolumn{2}{|c|}{$\begin{array}{c}5.20 \\
.219 \\
.84\end{array}$} & \multicolumn{2}{|c|}{$\begin{array}{l}.13 \\
.180 \\
.84 \\
\end{array}$} & \multicolumn{2}{|c|}{$\begin{array}{l}.11 \\
.175 \\
.89\end{array}$} & \multicolumn{2}{|c|}{$\begin{array}{l}4.96 \\
.183 \\
.77\end{array}$} & \multicolumn{2}{|c|}{$\begin{array}{l}5.53 \\
.218 \\
.80\end{array}$} \\
\hline $\begin{array}{l}\text { Exp. } \\
\text { No. } 4\end{array}$ & \multicolumn{3}{|c|}{ Minutes.......1 and 2} & \multicolumn{2}{|c|}{3 and 4} & \multicolumn{2}{|c|}{5 and 6} & \multicolumn{2}{|c|}{7 and 8} & \multicolumn{2}{|c|}{9 and 10} \\
\hline Exercise & $\begin{array}{l}\mathrm{MV} \\
\mathrm{O}_{2} \text { Uptake } \\
\mathrm{R}_{\mathrm{E}}\end{array}$ & \multicolumn{2}{|c|}{$\begin{array}{c}36.5 \\
1.795 \\
.78 \\
\end{array}$} & \multicolumn{2}{|c|}{$\begin{array}{c}56.6 \\
2.350 \\
.99\end{array}$} & \multicolumn{2}{|c|}{$\begin{array}{l}62.0 \\
2.520 \\
.98\end{array}$} & \multicolumn{2}{|c|}{$\begin{array}{c}67.8 \\
2.595 \\
.99\end{array}$} & \multicolumn{2}{|c|}{$\begin{array}{c}68.0 \\
2.495 \\
.95\end{array}$} \\
\hline $\begin{array}{l}\text { Exp. } \\
\text { No. } 5\end{array}$ & \multicolumn{3}{|c|}{ Minutes.......4 and 5} & \multicolumn{2}{|c|}{9 and 10} & \multicolumn{2}{|c|}{14 and 15} & \multicolumn{2}{|c|}{19 and 20} & & \\
\hline Exercise & $\begin{array}{l}\mathrm{MV} \\
\mathrm{O}_{2} \text { Uptake } \\
\mathrm{R}_{\mathrm{E}}\end{array}$ & & & & & & & & & & \\
\hline
\end{tabular}

* Exp. No. 1. Moderately well-trained laboratory worker, two hours after breakfast, recumbent 25 minutes before ten successive one-minute expired air samples were collected with no loss of expired air between samples. Douglas bags rinsed with room air before experiment. Valves turned at the minute regardless of phase of respiration. breaths.

Exp. No. 2. Highly trained subject under the same conditions. Valves turned during inspiration after each 12

Exp. No. 3. As in Exp. No. 2, but the valves were turned during inspiration after each 24 breaths.

Exp. No. 4. Normal subject, post-absorptive, walking at $3.5 \mathrm{mph}$., and on a 10 per cent grade on motor-driven treadmill. Successive two-minute collections made from the start of exercise.

Exp. No. 5. Normal subject, post-absorptive state, walking at $3.5 \mathrm{mph}$., on an 8 per cent grade. Two minute collections made at intervals as indicated.

it may not faithfully reflect overall body metabolism. This is the case, for example, during transient periods of hyperventilation. For purposes of this discussion, the $\mathrm{CO}_{2}-\mathrm{O}_{2}$ exchange ratio will be designated as $R_{E}$ or $R_{B}$ according to whether this ratio is calculated from analyses of inspired and expired gas, or from analyses of blood samples from the pulmonary and systemic arteries. $\mathbf{R}_{\mathbf{A}}$ will designate the ratio of $\mathrm{CO}_{2}$ and $\mathrm{O}_{2}$ exchange between alveolar gas and pulmonary capillary blood.

In Table I are presented data on normal subjects who were accustomed to breathing through a mouthpiece which was part of the open circuit routinely used in this laboratory. In these subjects, every effort was made to allow them to reach a steady state with respect to breathing pattern, $\mathrm{O}_{2}$ uptake, and R.Q. It is evident that at rest, and to a lesser extent during 10 to 20 minutes of exercise, there are fluctuations in $\mathrm{R}_{\mathrm{E}}$ and $\mathrm{O}_{2}$ uptake which cannot be accounted for on the basis of errors in Haldane analysis. The cause of these fluctuations is not immediately apparent but they bear on the concept of the steady state.

Cournand (12) has reported that $R_{\mathbb{E}}$ determined over a one to two minute period from analyses of expired gas does not always agree with $R_{B}$ determined from analyses of the concurrently obtained mixed venous and systemic arterial blood of resting subjects. Occasionally, similar discrepancies between $R_{E}$ and $R_{B}$ have been observed in this laboratory in studies (13) carried out on anesthetized dogs even though the collec- 
tions of gas and blood were made simultaneously over a period of several minutes. The influence of analytical errors in blood and gas analysis on the calculated values for $R_{E}$ and $R_{B}$ may explain such discrepancies in some instances. Consideration of other factors which might explain these discrepancies is of interest, however, in regard to the practical application of the Bohr relation for calculating alveolar $\mathrm{PO}_{2}$.

During changes in tidal volume, respiratory rate and functional residual capacity, the composition of expired gas varies in a complex fashion which is not entirely determined by $\mathrm{CO}_{2}$ and $\mathrm{O}_{2}$ exchange between blood and alveolar gas. With brief periods of hyperventilation, for example, the Haldane-Priestley alveolar $\mathrm{PCO}_{2}$ drops 10 to $20 \mathrm{~mm}$. $\mathrm{Hg}$ (14) and the $\mathrm{CO}_{2}$ output measured from expired gas increases abruptly with very little change in $\mathrm{O}_{2}$ uptake. If any $\mathrm{CO}_{2}$ entering the expired gas cannot be accounted for by loss of $\mathrm{CO}_{2}$ from the blood, $R_{E}$ will be greater than $R_{B}$ during the period of gas collection. Dubois, Fenn, and Britt (15) have estimated that lungs from which blood has been removed can take up (and therefore unload) about $0.23 \mathrm{cc}$. of $\mathrm{CO}_{2}$ per $100 \mathrm{Gm}$. of lung tissue per $\mathrm{mm}$. of change in $\mathrm{CO}_{2}$ tension. Since $\mathrm{CO}_{2}$ diffuses through body tissues quite rapidly, it is possible that a drop of $10 \mathrm{~mm}$. $\mathrm{Hg}$ in alveolar $\mathrm{PCO}_{2}$ could result in the excretion of $23 \mathrm{cc}$. of $\mathrm{CO}_{2}$ from a kilogram of lung tissue.

When the functional residual capacity decreases, as it may during a brief period of observation, a higher concentration of $\mathrm{CO}_{2}$ is found in the expired gas. The $R_{E}$ will show no change as a result of such a change in functional residual capacity when the distribution of alveolar gas is uniform; however, when alveolar gas composition varies in different parts of the lung, a change in functional residual capacity may produce a change in $R_{E}$ without there being a simultaneous change in $R_{\mathbf{A}}$.

If $R_{E}$ is as much as 0.04 unit greater than $R_{\mathbf{A}}$ during a short period of expired gas and arterial blood collection, the calculated alveolar $\mathrm{Po}_{2}$ works out to be about $2 \mathrm{~mm}$. too high. Since many patients tend to hyperventilate when breathing through a mouthpiece and since even in the trained normal subjects of Table I minute to minute $R_{\mathbf{E}}$ variations of 0.04 unit frequently occur, it is evident that the calculated alveolar $\mathrm{Po}_{2}$ must be inter- preted with due regard to the conditions required for its valid calculation.

There remains to be considered the assumption of Rossier and Blickenstorfer (10) and Riley, Lilienthal, Proemmel, and Franke (11) that equilibrium with respect to $\mathrm{CO}_{2}$ is attained between alveolar gas and pulmonary capillary blood. There is little doubt that this assumption is justified when it is made with respect to normal animals and man at rest for it has been repeatedly shown $(9,16,17)$ that when alveolar gas is properly sampled its $\mathrm{CO}_{2}$ tension is equal to that in arterial blood. Proof is needed, however, that this assumption is valid during the greater output of $\mathrm{CO}_{2}$ that accompanies exercise.

Riley, Lilienthal, Proemmel, and Franke (11) using the Boothby modification of the HaldanePriestley technique and other investigators (18) using an "end tidal" sampling device (19) found that the $\mathrm{PCO}_{2}$ of directly sampled alveolar gas averaged 12.7 and $1.8 \mathrm{~mm}$. $\mathrm{Hg}$ higher than the $\mathrm{PCO}_{2}$ of simultaneously sampled arterial blood in normal subjects during exercise. Data obtained by us on normal men during exercise, using the Muller trap as modified by Henderson and Haggard (20), are presented in Table II. We found the average "alveolar $\mathrm{PCO}_{2}$ " obtained thus to be $2.3 \mathrm{~mm}$. $\mathrm{Hg}$ higher than that of arterial blood simultaneously sampled. That the difference observed by other investigators (18) and by us is so much less than that reported by Riley is obviously in a large measure accounted for by the methods used to obtain the "alveolar" sample. The theoretical analysis by Dubois (21) of the probable cyclic changes in alveolar $\mathrm{PCO}_{2}$ emphasizes the necessity for cir-

TABLE II

The mean of measurements of $P_{C}, P_{O_{2}}$ and $R$ of end-tidal samples compared with the mean of values in arterial blood, alveolar gas (calculated) and expired gas-The data were obtained during exercise in 30 of the normal subjects of Table IV

\begin{tabular}{lccc}
\hline \hline & $\mathrm{PcO}_{2}$ & $\mathrm{Po}_{2}$ & $\mathrm{R}$ \\
\hline & $\mathrm{mm} . \mathrm{Hg}$ & $\mathrm{mm} . \mathrm{Hg}$ & \\
& 40.1 & 98.6 & .928 \\
$\begin{array}{l}\text { End-tidal } \\
\text { Arterial }\end{array}$ & 37.8 & 102.5 & \\
$\begin{array}{l}\text { Calculated alveolar } \\
\begin{array}{l}\text { Mxpired } \\
\text { Mean of individual differ- } \\
\text { ences }\end{array}\end{array}$ & 2.3 & 3.9 & .044 \\
$\begin{array}{l}\text { S.E. of mean of individual } \\
\text { differences }\end{array}$ & .73 & .91 & .007 \\
\hline
\end{tabular}


cumspection in the interpretation of data obtained by the direct sampling of alveolar gas.

If the diffusion theory of alveolar gas exchange is accepted, the $\mathrm{PCO}_{2}$ of gas to which pulmonary blood is exposed cannot be higher than the $\mathrm{PCO}_{2}$ of blood flowing from the alveolar capillaries. Roughton's work (22) indicates that alveolar capillary blood does not decrease in $\mathrm{CO}_{2}$ tension as it flows to the peripheral arteries and hence it is unlikely that arterial $\mathrm{PCO}_{2}$ is ever lower than that of the alveolar spaces. Data available by direct sampling show the alveolar $\mathrm{PCO}_{2}$ to be consistently higher than that of arterial and presumably capillary blood. The discrepancy in this direction is understandable on the basis of inadequate methods for obtaining a true sample of gas from the alveoli and since no one has demonstrated discrepancies of opposite sign in normal persons, the data can be taken to support the assumption that the arterial $\mathrm{PCO}_{2}$ and alveolar $\mathrm{PCO}_{2}$ are virtually equal during exercise as well as at rest in normal subjects.

The experimental data of Table II nicely demonstrate the type of error that is produced by a direct sampling method for measuring end-tidal gas concentrations during exercise. The end-tidal $\mathrm{PO}_{2}$ was $3.9 \mathrm{~mm}$. $\mathrm{Hg}$ less than the calculated alveolar $\mathrm{Po}_{2}$. Of this difference, $2.3 \mathrm{~mm}$. $\mathrm{Hg}$ can be accounted for by the fact that the end-tidal $\mathrm{PCO}_{2}$ was $2.3 \mathrm{~mm}$. $\mathrm{Hg}$ less than in arterial blood. The remaining $1.6 \mathrm{~mm}$. $\mathrm{Hg}$ can be accounted for by the fact that the end-tidal $R$ is significantly less than the $R$ of mixed expired gas as would be expected from the work of Stacy and Kydd (23). Considering the blood dissociation curves and diffusion characteristics of $\mathrm{O}_{2}$ and $\mathrm{CO}_{2}$, it is probable that toward the end of an expiration the rate of $\mathrm{O}_{2}$ uptake and therefore loss of $\mathrm{O}_{2}$ from alveolar gas remains quite rapid even though the output of $\mathrm{CO}_{2}$ from the blood has diminished. For this reason, the end-tidal $\mathrm{PO}_{2}$ deviates more widely from the true alveolar value than does the end-tidal $\mathrm{PCO}_{2}$.

From the above discussion, one can conclude that the requirements for the indirect calculation of the alveolar $\mathrm{PO}_{2}$ by the method of Riley and Cournand (7) can under ideal circumstances be satisfied in normal men. Nevertheless, the method is quite sensitive to fluctuations of the pattern of breathing and the ideal circumstances required are so strict that they may commonly not be achieved (24). Moreover, to apply the method in diseased persons still requires proof that there is no barrier to the diffusion of $\mathrm{CO}_{2}$ across the alveolar membrane in these subjects. Available data from this laboratory can be interpreted to show that in some pathological conditions diffusely involving the lung the arterial $\mathrm{PCO}_{2}$ actually exceeds that of the alveolar gas.

\section{The Aa Difference in Normal Men at Rest and during Exercise}

\section{METHODS}

Arterial blood and expired gas samples were obtained at rest and during exercise from 36 normal males who were also extensively studied with regard to other pulmonary functions. Their mean age was 41 years, the extremes being 23 and 60 years.

The subjects were studied at least one hour after their last meal. After the subject =ested on a bed for $20 \mathrm{~min}$ utes, an indwelling No. 20 needle was placed in a brachial or radial artery. For experiments under resting conditions, another 10 minutes were allowed to elapse before the subject began to breathe through a mouthpiece connected to one-way valves, flushing for 5 minutes the expiratory side of the rubber tubing leading to Douglas bags (previously rinsed with room air). A preliminary expired air collection of two or six minutes' duration was then made. Another bag was so connected that without loss of expired gas a 75 to 120 -second collection could be made simultaneously with the slow and even sampling of $15 \mathrm{cc}$. of arterial blood. The gas was collected beginning at the first inspiration after blood appeared in the syringe and ending with the first inspiration after blood sampling was completed. Respirations were counted during this accurately timed period.

In exercise experiments, a grade and speed ( 8 to 12 per cent, 3 to $3.5 \mathrm{mph}$.) on a motor-driven treadmill were chosen such that the subject's $\mathrm{O}_{2}$ uptake was approximately 75 per cent of the maximum of which he was capable. With the arterial needle in place, the subject walked for 5.5 to 6 minutes, rinsing the Henderson-Haggard trap (20) for the continuous collection of end-tidal gas, and achieving a state of exercise such that nearly constant values for minute ventilation, $\mathrm{O}_{2}$ uptake, $R_{\mathbb{B}}$ and pulse rate were reached. During the last 60 to 100 seconds of the walk, $15 \mathrm{cc}$. of arterial blood were withdrawn simultaneously with the collection of expired and end-tidal gas, and respirations were counted during this accurately timed period.

Expired gas was measured and sampled and was analyzed in duplicate in the Haldane apparatus. Checks within 0.04 vol. per cent for $\mathrm{O}_{2}$ and $\mathrm{CO}_{2}$ were required. Arterial blood, collected in a syringe whose dead space was obliterated by a heparin-sodium fluoride mixture, was analyzed in duplicate for $\mathrm{O}_{2}$ and $\mathrm{CO}_{2}$ content by the method of Van Slyke and Neill (25) within an hour after blood-sampling. The syringe was rotated inside 
TABLE III

Respiratory and arterial blood measurements in 19 subjects at rest*

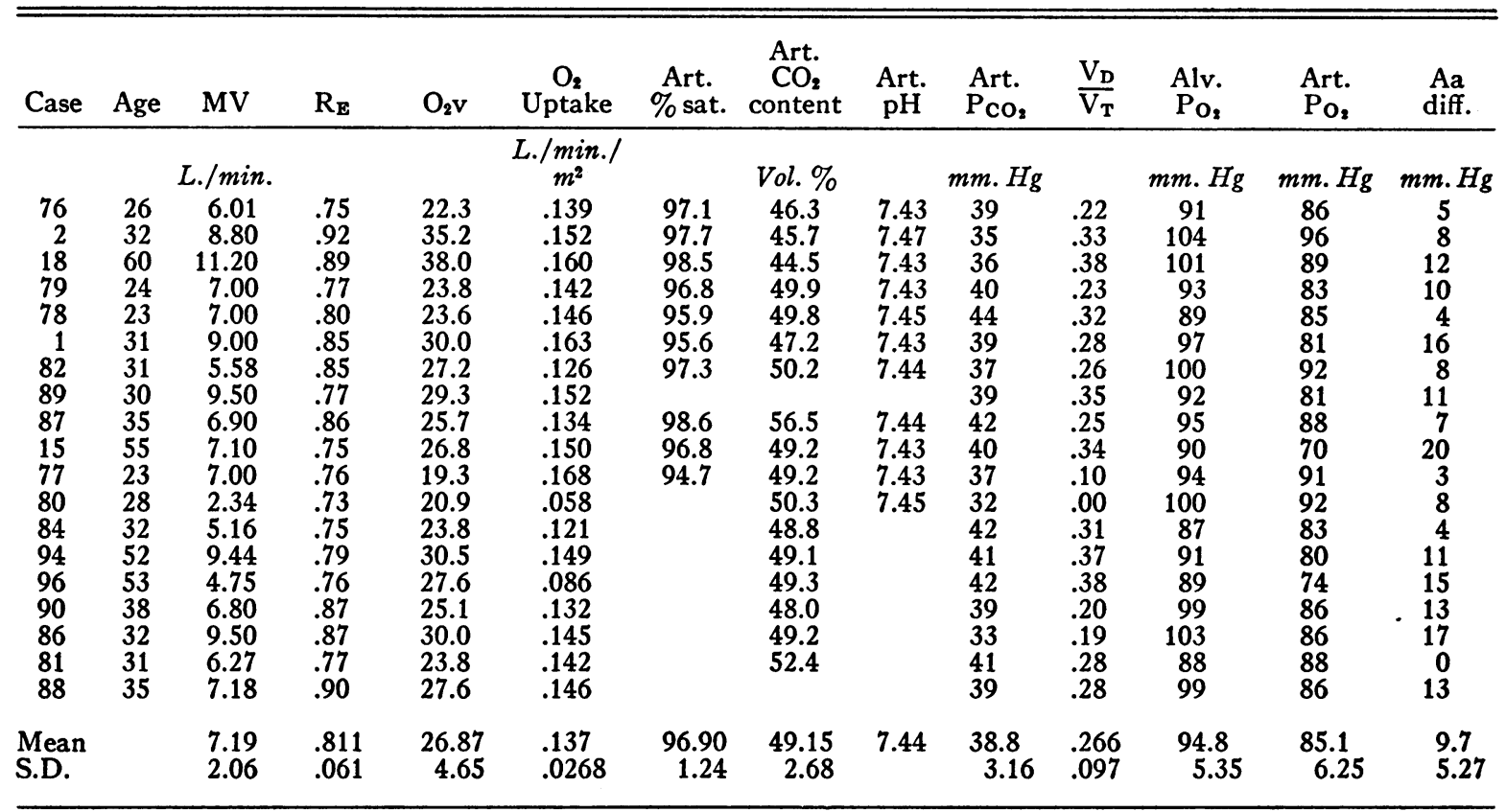

* In the first seven subjects all analytical criteria (see Discussion) were satisfied. The mean Aa difference in these subjects was $9.0 \mathrm{~mm}$. $\mathrm{Hg}$ with a standard deviation of $3.61 \mathrm{~mm}$. $\mathrm{Hg}$.

a refrigerator in the interval between sampling and analysis. Oxygen capacity was determined by the method of Sendroy (26) with slight modifications (1). The $\mathrm{pH}$ of arterial blood plasma was determined by the method of Hastings and Sendroy (27). Arterial $\mathrm{O}_{2}$ and $\mathrm{CO}_{2}$ tensions were determined in duplicate within nine minutes after blood sampling by the method of Riley, Proemmel, and Franke (28) in 31 analyses and by a modification of this method elsewhere described (1) in 22 analyses. Checks within $6 \mathrm{~mm}$. $\mathrm{Hg}$ were required.

Minute ventilation (MV) was expressed as liters of expired gas per minute at $37^{\circ} \mathrm{C}$., ambient pressure, and saturated with water vapor at Tissot temperature. Tidal volume $\left(V_{T}\right)=M V /$ respiratory rate. Oxygen uptake was expressed in liters of $\mathrm{O}_{2}$ (STPD) per minute. The $\mathrm{O}_{2}$ ventilation equivalent $\left(\mathrm{O}_{2} \mathrm{v}\right)$ was defined as $\mathrm{MV} / \mathrm{O}_{2}$ uptake. Alveolar $\mathrm{Po}_{2}$ and the physiological dead space $\left(V_{D}\right)$ were calculated by formulas 12 and 13 in the paper by Riley and Cournand (7). In calculating $V_{D} / V_{T}$ the apparatus dead space was not subtracted from $V_{\mathbf{T}}$.

\section{RESULTS}

The results of the studies at rest are shown in Table III. The mean of the calculated alveolar $\mathrm{O}_{2}$ tension was $94.8 \mathrm{~mm}$. $\mathrm{Hg}$ or 13.2 per cent of the mean barometric pressure in this laboratory (elevation 1,600 feet). The mean of the arterial $\mathrm{Po}_{2}$ was $85.1 \mathrm{~mm}$. $\mathrm{Hg}$. The alveolar-arterial $\mathrm{O}_{2}$ ten- sion differences averaged $9.7 \mathrm{~mm}$. $\mathrm{Hg}$, the extremes being 0 and $20 \mathrm{~mm}$. $\mathrm{Hg}$.

The studies performed on normal men during exercise are shown in Table IV. The mean of the calculated alveolar $\mathrm{O}_{2}$ tension was $102.1 \mathrm{~mm}$. $\mathrm{Hg}$ or 14.2 per cent of the mean barometric pressure. The mean of the arterial $\mathrm{Po}_{2}$ was $82.5 \mathrm{~mm}$. $\mathrm{Hg}$ giving a mean for the Aa difference of $19.6 \mathrm{~mm}$. $\mathrm{Hg}$ with extremes of 11 to $27 \mathrm{~mm}$. $\mathrm{Hg}$.

At rest the variations from subject to subject in minute ventilation and $\mathrm{O}_{2}$ uptake per square meter of body surface were as anticipated. The variations in the $\mathrm{O}_{2}$ ventilation equivalent and $\mathrm{R}_{\mathrm{E}}$ were outside the limits of analytical error. The variations in alveolar and arterial gas tensions were somewhat greater than should result from analytical error alone (1). In an effort to account for these variations, correlation studies were carried out. Table V shows that at rest, as expected, there was a positive correlation between the minute ventilation and $R_{E}$. A more definite positive correlation existed between the resting ventilation equivalent $\left(\mathrm{O}_{2} \mathrm{v}\right)$ and $\mathrm{R}_{\mathrm{E}}$ indicating that even slight overbreathing resulted in an elevation of $R_{E}$. There was a definite tendency during rest for over-breath- 
TABLE IV

Respiratory and arterial blood measurements in 34 subjects during moderately severe treadmill exercise *

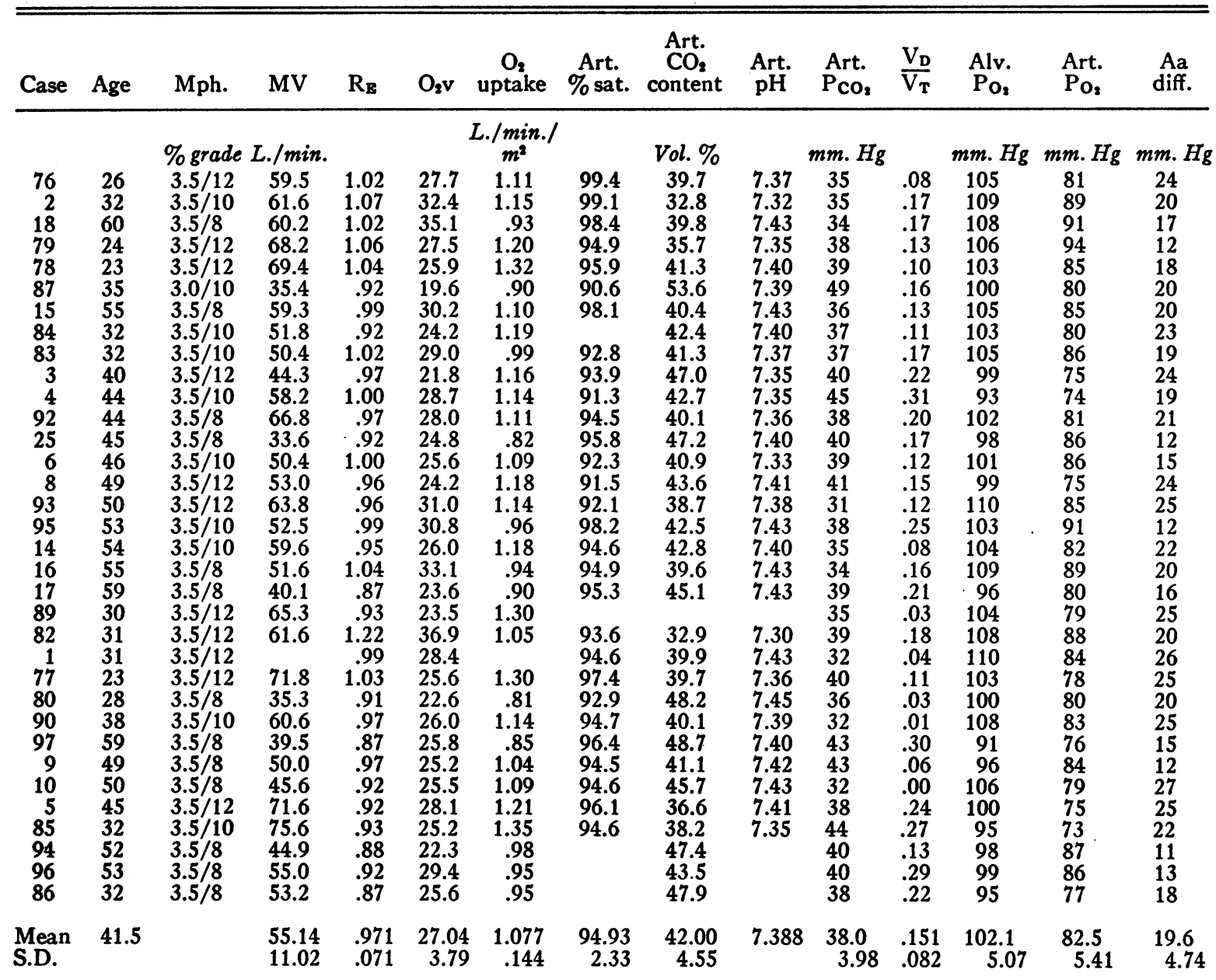

* In the last 11 subjects listed not all analytical criteria were satisfied. The mean Aa difference in these 11 subjects was $19.4 \mathrm{~mm}$. $\mathrm{Hg}$.

TABLE V

The relation of the minute ventilation and the oxygen ventilation equivalent to the respiratory quotient and alveolar and arterial $P_{O_{2}}$ in 19 subjects at rest and 34 subjects during exercise

\begin{tabular}{|c|c|c|c|c|c|c|c|c|}
\hline & \multicolumn{4}{|c|}{ Resting } & \multicolumn{4}{|c|}{ Exercise } \\
\hline & $\mathrm{N}$ & "r" & S.E. & $\mathbf{P}$ & $\mathrm{N}$ & "r" & S.E. & $\mathbf{P}$ \\
\hline $\begin{array}{l}\text { MV vs. } R_{\mathbf{S}} \\
\text { MV vs. Alveolar } \mathrm{Po}_{2} \\
\text { MV vs. Arterial } \mathrm{PO}_{\mathrm{O}} \\
\text { MV vs. Aa difference }\end{array}$ & $\begin{array}{l}19 \\
19 \\
19 \\
19\end{array}$ & $\begin{array}{r}.546 \\
.276 \\
-.046 \\
.337\end{array}$ & $\begin{array}{l}.166 \\
.056 \\
.024 \\
.209\end{array}$ & $\begin{array}{l}>.01 \\
>.1 \\
>.1\end{array}$ & $\begin{array}{l}33 \\
33 \\
33 \\
33\end{array}$ & $\begin{array}{l}.440 \\
.353 \\
.021 \\
.349\end{array}$ & $\begin{array}{l}.143 \\
.155 \\
.177 \\
.155\end{array}$ & $\begin{array}{r}.01 \\
.05 \\
>.1 \\
.05\end{array}$ \\
\hline $\begin{array}{l}\mathrm{O}_{2} \mathrm{v} \text { vs. } \mathrm{R}_{\mathrm{E}} \\
\mathrm{O}_{2 \mathrm{v}} \text { vs. Alveolar } \mathrm{Po}_{2} \\
\mathrm{O}_{2 \mathrm{v}} \mathrm{vs} \text {. Arterial } \mathrm{PO}_{2} \\
\mathrm{O}_{2} \mathrm{v} \text { vs. Aa difference }\end{array}$ & $\begin{array}{l}19 \\
19 \\
19 \\
19\end{array}$ & $\begin{array}{l}.673 \\
.473 \\
.003 \\
.479\end{array}$ & $\begin{array}{l}.129 \\
.183 \\
.236 \\
.182\end{array}$ & $\begin{array}{l}<.001 \\
.05 \\
>.1 \\
.05\end{array}$ & $\begin{array}{l}34 \\
34 \\
34 \\
34\end{array}$ & $\begin{array}{r}.683 \\
.548 \\
.546 \\
-.035\end{array}$ & $\begin{array}{l}.093 \\
.122 \\
.122 \\
.174\end{array}$ & $\begin{array}{r}<.001 \\
.001 \\
.001 \\
>.1\end{array}$ \\
\hline
\end{tabular}


TABLE VI

Comparison of mean values obtained at rest (19 cases) and during strenuous exercise (34 cases)

\begin{tabular}{|c|c|c|c|c|}
\hline & Rest & Exercise & $\begin{array}{l}\text { Differ- } \\
\text { ence of } \\
\text { means }\end{array}$ & $\begin{array}{l}\text { S.E. of } \\
\text { difference } \\
\text { of means }\end{array}$ \\
\hline $\begin{array}{l}\text { Calc. alv. } \mathrm{PO}_{2} \\
\text { Art. } \mathrm{PO}_{2} \\
\text { Aa difference } \\
\% \mathrm{O}_{2} \text { sat. } \\
\mathrm{CO}_{2} \text { content } \\
{\text { Art. } \mathrm{P}_{\mathrm{CO}_{2}}}_{\mathrm{O}_{2} \mathrm{v}} \\
\mathrm{V}_{\mathrm{D}} / \mathrm{V}_{\mathrm{T}}\end{array}$ & $\begin{array}{c}94.8 \\
85.1 \\
9.7 \\
96.90 \\
49.15 \\
38.8 \\
26.87 \\
.266\end{array}$ & $\begin{array}{c}102.1 \\
82.5 \\
19.6 \\
94.93 \\
42.00 \\
38.0 \\
27.04 \\
.151\end{array}$ & $\begin{array}{l}7.3 \\
2.6 \\
9.9 \\
1.97 \\
7.15 \\
0.8 \\
0.17 \\
.115\end{array}$ & $\begin{array}{l}1.503 \\
1.706 \\
1.456 \\
0.583 \\
1.024 \\
0.995 \\
1.249 \\
0.027\end{array}$ \\
\hline
\end{tabular}

ing, as defined by an increased $\mathrm{O}_{2} \mathrm{v}$, to be associated with an increased $\mathrm{Aa}$ difference. This increase resulted from an elevated calculated alveolar $\mathrm{PO}_{2}$ in association with over-breathing. During exercise, these relationships were similar except for the fact that the Aa difference bore no relationship to the $\mathrm{O}_{2}$ v.

The mean values obtained at rest are compared with those of the exercise studies in Table VI. The statistically significant increase in the $\mathrm{Aa}$ difference was largely the result of the marked rise in alveolar $\mathrm{PO}_{2}$ although a slight but not significant decrease in arterial $\mathrm{Po}_{2}$ also occurred. The decrease in the per cent saturation of the arterial hemoglobin with exercise, though small, was a significant one. The decrease in $\mathrm{CO}_{2}$ content of 7.15 vol. per cent was highly significant. The mean arterial $\mathrm{PCO}_{2}$ showed an insignificant difference between the resting and exercise values. The mean $\mathrm{O}_{2} \mathrm{v}$ was virtually identical at rest and during exercise.

The ratio of physiological dead space to tidal volume was significantly lower during exercise than at rest; under both conditions, this ratio had a wide range of values. Occasionally, both during rest and exercise, the arterial $\mathrm{PCO}_{2}$ was so slightly greater than the expired $\mathrm{PCO}_{2}$ that the calculated physiological dead space was zero.

\section{DISCUSSION}

The difference between alveolar and peripheral arterial $\mathrm{O}_{2}$ tension has been reported (29-31) to lie between 0 and $25 \mathrm{~mm}$. $\mathrm{Hg}$ in normal resting subjects. It is generally agreed that the $\mathrm{PO}_{2}$ of blood removed from the peripheral arteries can now be measured directly with an accuracy of $\pm 2 \mathrm{~mm}$.
$\mathrm{Hg}$ and that, if determined immediately after obtaining the blood sample, the measurement faithfully represents the $\mathrm{PO}_{2}$ of blood flowing through the peripheral arteries. Unfortunately, in earlier studies, the arterial $\mathrm{PO}_{2}$ was measured by indirect methods in which the error may be considerably greater; hence, the variation of Aa difference reported in the literature may in part be accounted for on the basis of the technique for measuring arterial $\mathrm{Po}_{2}$. Previous methods for measuring an alveolar $\mathrm{PO}_{2}$ as well as the values obtained have varied considerably. For reasons discussed earlier in this paper, we believe that direct sampling fails from both a spatial and temporal point of view to give a faithful moiety of the gas from or representative of that within the alveoli of the lungs. We prefer the indirect method of measuring an alveolar $\mathrm{PO}_{2}$ even though the method is based upon assumptions that at times are not fulfilled in actual practice. Moreover, we prefer to designate the value as an alveolar $\mathrm{Po}_{2}$ rather than the alveolar $\mathrm{Po}_{2}$ since the latter at any one moment undoubtedly has various values at different places within the lungs, all of which vary during the course of each respiratory cycle. Furthermore, it must be apparent that the indirectly calculated alveolar $\mathrm{PO}_{2}$ can be considered as representative of alveolar gas only in the limited sense that arterial $\mathrm{PCO}_{2}$ actually represents alveolar $\mathrm{PCO}_{2}$. In essence, the "alveolar $\mathrm{PCO}_{2}$ and $\mathrm{Po}_{2}$ " obtained by indirect methods are an integration of spatially and temporally fluctuating alveolar $\mathrm{Po}_{2}$ 's and $\mathrm{PCO}_{2}$ 's which are so related as to give the actual arterial $\mathrm{PCO}_{2}$ and expired air R.Q. that is obtained by direct measurement. What is actually done is to measure directly the gas tensions of expired air and arterial blood and conclude that in order for the blood leaving the lungs and the R.Q. of expired air to be as actually measured, the integrated alveolar $\mathrm{O}_{2}$ tension to which the blood was exposed must have been as calculated.

Our data clearly support those who contend that the indirectly calculated alveolar $\mathrm{Po}_{2}$ is normally higher than the arterial $\mathrm{Po}_{2}$. As will be discussed later, the random character of the variation in the calculated alveolar $\mathrm{PO}_{2}$ is evidence that the higher alveolar $\mathrm{Po}_{2}$ is not purely a technical error.

The variation in the Aa difference among normal recumbent individuals (Table III) is somewhat greater than that reported by Lilienthal, 
GILES F. FILLEY, FERNAND GREgOIRE, AND GEORGE W. WRIGHT

TABLE VII

The results of all arterial blood studies that have been performed on Subject No. $84^{*}$

\begin{tabular}{|c|c|c|c|c|c|c|c|c|c|c|c|}
\hline Condition & Date & MV & $\mathrm{V}_{\mathbf{T}}$ & $\mathbf{R}_{\mathbf{E}}$ & $\mathrm{O}_{2} \mathrm{v}$ & $\begin{array}{c}\mathrm{O}_{2} \\
\text { uptake }\end{array}$ & $\begin{array}{l}\text { Art. } \\
\mathrm{PCO}_{2}\end{array}$ & $\frac{V_{D}}{V_{T}}$ & $\begin{array}{l}\text { Alv. } \\
\mathrm{PO}_{2}\end{array}$ & $\begin{array}{l}\text { Art. } \\
\mathrm{Po}_{2}\end{array}$ & $\begin{array}{c}\mathrm{Aa} \\
\text { diff. }\end{array}$ \\
\hline & & L./min. & $c c$ & & & L. $/ \min . / m^{2}$ & $m m . H g$ & & $m m . H g$ & $m m . H g$ & $\overline{m m . H g}$ \\
\hline $\begin{array}{l}\text { Resting } \\
\text { Resting } \\
\text { Resting } \\
\text { Resting } \\
\text { Resting } \\
\text { Resting } \\
\text { Resting } \\
\text { Resting } \\
\text { Resting } \\
\text { Resting } \\
\text { Resting }\end{array}$ & $\begin{array}{r}9 / 8 / 47 \\
11 / 12 / 47 \\
11 / 13 / 47 \\
11 / 13 / 47 \\
11 / 28 / 47 \\
9 / 14 / 47 \\
9 / 14 / 47 \\
9 / 14 / 47 \\
9 / 14 / 47 \\
9 / 14 / 47 \\
12 / 8 / 49\end{array}$ & $\begin{array}{l}4.81 \\
5.17 \\
7.78 \\
6.70 \\
5.75 \\
5.71 \\
5.98 \\
6.36 \\
6.02 \\
5.73 \\
6.73\end{array}$ & $\begin{array}{l}610 \\
638 \\
670 \\
770 \\
570 \\
794 \\
786 \\
795 \\
782 \\
726 \\
750\end{array}$ & $\begin{array}{l}.71 \\
.75 \\
.77 \\
.71 \\
.64 \\
.73 \\
.73 \\
.78 \\
.75 \\
.73 \\
.77\end{array}$ & $\begin{array}{l}23.8 \\
23.8 \\
28.4 \\
25.5 \\
24.4 \\
24.3 \\
23.1 \\
25.4 \\
24.1 \\
24.1 \\
24.7\end{array}$ & $\begin{array}{l}.112 \\
.113 \\
.152 \\
.146 \\
.131 \\
.131 \\
.144 \\
.139 \\
.139 \\
.132 \\
.151\end{array}$ & $\begin{array}{l}37 \\
42 \\
45 \\
47 \\
40 \\
39 \\
44 \\
40 \\
40 \\
42 \\
41\end{array}$ & $\begin{array}{l}.22 \\
.31 \\
.42 \\
.45 \\
.37 \\
.33 \\
.34 \\
.30 \\
.29 \\
.32 \\
.31\end{array}$ & $\begin{array}{l}94 \\
87 \\
85 \\
79 \\
82 \\
91 \\
85 \\
93 \\
91 \\
87 \\
90\end{array}$ & $\begin{array}{l}83 \\
83 \\
78 \\
79 \\
74 \\
83 \\
83 \\
88 \\
85 \\
87 \\
81\end{array}$ & $\begin{array}{r}11 \\
4 \\
7 \\
0 \\
8 \\
8 \\
2 \\
5 \\
6 \\
0 \\
9\end{array}$ \\
\hline Mean & & 6.07 & 716 & .734 & 24.69 & .136 & 41.5 & .337 & 87.6 & 82.2 & 5.5 \\
\hline $\begin{array}{l}2 \% \text { Grade } \\
2 \% \text { Grade } \\
2 \% \text { Grade } \\
2 \% \text { Grade } \\
6 \% \text { Grade } \\
6 \% \text { Grade } \\
10 \% \text { Grade } \\
10 \% \text { Grade } \\
10 \% \text { Grade } \\
16 \% \text { Grade }\end{array}$ & $\begin{array}{r}10 / 16 / 50 \\
10 / 18 / 50 \\
3 / 12 / 51 \\
3 / 27 / 51 \\
10 / 16 / 50 \\
10 / 18 / 50 \\
8 / 10 / 48 \\
10 / 16 / 50 \\
10 / 18 / 50 \\
12 / 9 / 52\end{array}$ & $\begin{array}{r}29.4 \\
30.1 \\
31.3 \\
38.0 \\
47.1 \\
40.1 \\
51.8 \\
62.5 \\
62.0 \\
116.0\end{array}$ & $\begin{array}{l}1960 \\
2110 \\
2060 \\
1960 \\
1860 \\
1950 \\
2630 \\
2320 \\
2660 \\
2970\end{array}$ & $\begin{array}{r}.94 \\
.90 \\
.88 \\
.93 \\
1.01 \\
.98 \\
.92 \\
1.05 \\
1.03 \\
1.13\end{array}$ & $\begin{array}{l}23.6 \\
24.0 \\
23.0 \\
26.6 \\
28.0 \\
26.7 \\
24.2 \\
29.1 \\
29.7 \\
42.8\end{array}$ & $\begin{array}{l}.677 \\
.682 \\
.740 \\
.775 \\
.934 \\
.836 \\
1.160 \\
1.190 \\
1.160 \\
1.480\end{array}$ & $\begin{array}{l}43 \\
41 \\
41 \\
39 \\
39 \\
38 \\
37 \\
39 \\
33 \\
30\end{array}$ & $\begin{array}{l}.20 \\
.21 \\
.18 \\
.21 \\
.18 \\
.14 \\
.11 \\
.19 \\
.09 \\
.23\end{array}$ & $\begin{array}{r}99 \\
98 \\
97 \\
101 \\
105 \\
104 \\
102 \\
106 \\
110 \\
115\end{array}$ & $\begin{array}{l}90 \\
85 \\
83 \\
91 \\
88 \\
88 \\
80 \\
92 \\
86 \\
89\end{array}$ & $\begin{array}{r}99 \\
13 \\
14 \\
10 \\
17 \\
16 \\
22 \\
14 \\
24 \\
26\end{array}$ \\
\hline
\end{tabular}

* The speed of treadmill walking was $3.5 \mathrm{mph}$.

Riley, Proemmel, and Franke (30) in six men under similar experimental conditions. To what extent are our results influenced by (a) analytical errors, (b) failure to fulfill the experimental conditions required for the valid calculation of alveolar $\mathrm{Po}_{2}$, (c) physiologic differences among normal men caused by psychological stimuli associated with taking of biological samples, and (d) actual physiologic differences between normal persons?

In order to explore the influence of analytical errors, it is necessary to eliminate so far as possible the influence of factors (b), (c), and (d). With this in mind, 12 separate determinations of the alveolar-arterial $\mathrm{O}_{2}$ tension difference were made in the same trained normal subject (Case 84) at rest. The subject was thoroughly accustomed to breathing through a mouthpiece and showed somewhat smaller minute to minute variations in his $R_{\mathbf{E}}$ than most trained subjects. The results of these experiments (Table VII) show that even when factors (b), (c), and (d) are held as constant as possible the variation of the alveolar-arterial $\mathrm{O}_{2}$ tension difference was of the same order as in the entire group of persons studied as shown in Table III. The analytical error of our blood gas tension determinations averages about $\pm 2 \mathrm{~mm}$.
$\mathrm{Hg}$ both for $\mathrm{O}_{2}$ and $\mathrm{CO}_{2}$ (1). Errors of this magnitude can result in an error of approximately $\pm 4 \mathrm{~mm}$. $\mathrm{Hg}$ in the difference between calculated alveolar and determined arterial $\mathrm{O}_{2}$ tension. Since the mean of this difference, repeatedly determined in the same subject, was $5.5 \mathrm{~mm}$. $\mathrm{Hg}$ with a standard deviation of $3.77 \mathrm{~mm}$. $\mathrm{Hg}$, it would appear that analytical errors account in part, but not entirely, for the variations observed.

It has been suggested ( 7 ) that technical errors can be minimized by consideration of other data related to blood gas tension determinations. The following criteria define an analytically satisfactory experiment in our laboratory:

(i) The directly determined $\mathrm{PCO}_{2}$ must be within $4 \mathrm{~mm}$. $\mathrm{Hg}$ of that calculated (32) from $\mathrm{CO}_{2}$ content, $\mathrm{O}_{2}$ capacity and $\mathrm{pH}$ of arterial blood.

(ii) The physiological dead space must be greater than $50 \mathrm{cc}$. at rest and $100 \mathrm{cc}$. during exercise.

(iii) The $\mathrm{pH}$ calculated (32) from the directly determined $\mathrm{PCO}_{2}, \mathrm{CO}_{2}$ content and $\mathrm{O}_{2}$ capacity of arterial blood must agree within $0.03 \mathrm{pH}$ units with the directly determined $\mathrm{pH}$. 
(iv) The directly determined $\mathrm{Po}_{2}$ must lie within 15 per cent of that calculated from the standard dissociation curve (8), the $\mathrm{O}_{2}$ content and capacity and the $\mathrm{pH}$ of arterial blood.

Although these criteria are helpful in discovering gross errors, the alveolar-arterial $\mathrm{O}_{2}$ tension differences obtained in the experiments in which all of these criteria were satisfied were not significantly different from the figures for the subjects as a group as shown in Tables III and IV.

There is little doubt that the alveolar and arterial $\mathrm{CO}_{2}$ tensions are virtually equal in normal resting men. Whether or not it can be assumed that $R_{\mathbf{E}}$ exactly equalled the $\mathrm{CO}_{2}-\mathrm{O}_{2}$ exchange ratio at the "alveolar membrane" during the blood sampling period in our resting subjects is open to question, even though a period of rest long enough to obtain stabilization of the minute ventilation (33) was allowed to elapse before blood sampling began. For purposes of obtaining information for such short periods of sampling, we have routinely determined the expired $R_{E}$ both before and during the blood sampling period. The mean difference between the first and second $R_{E}$ of 167 clinical subjects was 0.0393 , a difference more than twice that to be expected from errors of Haldane analysis; the standard deviation of this difference was 0.0375. These data plus the minute-to-minute variations of $R_{E}$ shown for the trained subjects in Table I are clear evidence that a steady state is not commonly obtained under experimetal conditions. If, in addition to the effect of analytical errors, the calculated alveolar $\mathrm{PO}_{2}$ is also in error because of transient discrepancies between the $R_{E}$ of expired gas and that of pulmonary blood, the observed range of variation of the alveolar-arterial $\mathrm{O}_{2}$ tension difference in normal men at rest is readily explainable. However, this in no way invalidates the fact that an Aa difference normally exists at rest since both the analytical errors and the expired $R_{\mathbb{E}}$ variations are of a random character.

The fact that $R_{\mathbf{E}}$ varies from minute to minute both in patients and in normal subjects has an obvious bearing on the technique for collecting expired gas and arterial blood. When, for example, expired gas is collected for a longer period of time than arterial blood is sampled, the calculated alveo- lar $\mathrm{Po}_{2}$ will be in error to the extent that $\mathrm{R}_{\mathrm{E}}$ for the whole period of gas collection differs from the $\mathrm{R}_{\mathrm{E}}$ of the period of arterial blood sampling.

In attempting to find relationships between the blood gas data and the other measurements made simultaneously, we have observed that when overbreathing at rest occurs, as indicated by an elevated $\mathrm{O}_{2} \mathrm{v}$, the alveolar-arterial $\mathrm{O}_{2}$ tension difference tends to be elevated both in health and disease. It is known that voluntary hyperventilation at sea level can raise the alveolar $\mathrm{O}_{2}$ tension without producing a proportionate rise in the arterial $\mathrm{PO}_{2}$ (34) or arterial $\mathrm{O}_{2}$ saturation (35). Dill and Penrod have reported a similar relationship occurring in subjects at simulated altitudes (36) and pointed out that the explanation for this phenomenon is not clear. Since the resting minute ventilation of normal men breathing through a mouthpiece is often out of proportion to the metabolic demands of the body, probably because of psychological stimuli, it is reasonable to attribute some of the variations in the alveolar-arterial $\mathrm{O}_{2}$ tension difference seen in Table III to the variable respiratory response of each individual to the experimental procedure.

In view of factors (a), (b), and (c) it is questionable whether under resting conditions a single determination of the alveolar-arterial $\mathrm{O}_{2}$ tension difference can be considered characteristic for a given normal individual. We believe it will be necessary to make multiple determinations of the Aa difference in each of several individuals in order to disclose the extent to which persons truly differ from one another in this respect. Such data are not available.

The variation in the Aa difference in normal exercising men as expressed by the standard deviation of 4.74 is slightly less than the variation in this measurement at rest despite the fact that the exercise studies were carried out at various grades and speeds of treadmill walking. To investigate the effect of the severity of exercise on the Aa difference and other measurements, the exercise studies of Table VII were performed. The Aa difference rose progressively in this subject with increasing exercise primarily as a result of the increasing calculated alveolar $\mathrm{Po}_{2}$. This rising alveolar $\mathrm{Po}_{2}$ in turn resulted from a decrease in the ratio $V_{D} / V_{T}$. Since the analytical methods were the same in resting as in exercise studies, and since some variation among normal subjects would be expected to 
TABLE VIII

Mean values in normal subjects at rest and during varying amounts of exercise

\begin{tabular}{|c|c|c|c|c|c|c|}
\hline Subjects & $\begin{array}{c}\text { No. of } \\
\text { determi- } \\
\text { nations }\end{array}$ & Condition & $\mathrm{O}_{2}$ uptake & $\begin{array}{c}\text { Mixed } \\
\text { venous } \\
\% \text { sat. }\end{array}$ & Aa diff. & $\begin{array}{l}\% \text { Venous } \\
\text { admixture* }\end{array}$ \\
\hline \multirow{3}{*}{$\begin{array}{l}\text { Of Table III } \\
\text { Of Table IV }\end{array}$} & & & $L . / \min . / m^{2}$ & & $m m . H g$ & \\
\hline & 19 & Rest & .137 & 78 & 9.7 & 6.4 \\
\hline & 34 & $\begin{array}{l}\text { Moderate } \\
\text { exercise }\end{array}$ & 1.077 & 47 & 19.6 & 5.5 \\
\hline \multirow{5}{*}{ Subject No. 84} & 11 & Rest & .136 & 79 & 5.5 & 4.7 \\
\hline & 4 & $\begin{array}{l}\text { Light } \\
\text { exercise }\end{array}$ & .719 & 49 & 11.5 & 3.5 \\
\hline & 2 & $\begin{array}{l}\text { Moderate } \\
\text { exercise }\end{array}$ & .880 & 47.5 & 16.5 & 4.0 \\
\hline & 3 & $\begin{array}{l}\text { Heavy } \\
\text { exercise }\end{array}$ & 1.170 & 45 & 20.0 & 5.0 \\
\hline & 1 & $\begin{array}{l}\text { Exhausting } \\
\text { exercise }\end{array}$ & 1.480 & 30 & 26 & 4.5 \\
\hline
\end{tabular}

* The $\%$ venous admixture was calculated as follows:

$\%$ Venous admixture $=\frac{\text { Alveolar capillary \% sat. }- \text { Arterial } \% \text { sat. }}{\text { Alveolar capillary \% sat. }- \text { Mixed venous \% sat. }} \times 100$.

The alveolar capillary $\%$ saturation was calculated from the alveolar $\mathrm{P}_{\mathrm{O}_{3}}$ and the standard dissociation curve (8). See Text.

result from their exercising at different speeds and grades, some explanation is required for the relatively low standard deviation of the exercise Aa difference.

In the first place, as seen in Table $I$, there is less minute-to-minute change in minute ventilation and $\mathbf{R}_{\mathbf{E}}$ during exercise than at rest. For this reason it is likely that during exercise the conditions for the valid calculation of alveolar $\mathrm{Po}_{2}$ are more easily fulfilled than in the resting state. Secondly, there is less variation among normal individuals in the $\mathrm{O}_{2}$ ventilation equivalent during exercise than at rest. It seems reasonable to conclude, therefore, that during exercise the alveolar $\mathrm{PO}_{2}$ is less subject than at rest to errors caused by failure to maintain a steady state. The respiratory drive during exercise appears to be less affected by psychic stimuli than at rest; hence the value for the Aa difference is more likely to be characteristic for a given individual when he is exercising than when he is at rest. This conclusion is borne out by the results of the exercise studies on a single subject as seen in Table VI where, except in one instance, repeated determinations of the Aa difference under the same exercise conditions agreed more closely than they did at rest.

\section{An Interpretation of the Normal Aa Difference}

The experimental finding that alveolar $\mathrm{O}_{2}$ tension exceeds that in the arterial blood of normal men has been attributed to:

1) Experimental errors involved in sampling alveolar gas and analyzing arterial blood.

2) A change in the physico-chemical state of the blood in transit from lung to artery.

3) Failure of pulmonary capillary blood to reach alveolar $\mathrm{O}_{2}$ tension ("membrane factor").

4) The admixture of venous blood (via shunts) or partially oxygenated blood (via poorly ventilated alveoli) with pulmonary capillary blood ("venous admixture").

For reasons discussed earlier, the first explanation appears to be inadequate to explain the $\mathrm{Aa}$ difference observed in the present study. Considerable evidence against the validity of the second explanation has been marshalled by Roughton (22).

It appears likely (37) that equilibrium with respect to $\mathrm{O}_{2}$ is normally attained between alveolar capillary blood and alveolar gas in resting sub- 
jects (38). Whether or not this is true during heavy exercise is open to question since the time spent by pulmonary blood in the alveolar capillaries might be insufficient for complete equilibrium to be reached.

In the formulation by Riley and Cournand (7), both the "membrane factor" and the influence of venous admixture are dealt with in detail as explanations for an Aa difference determined under various conditions in normal persons. Riley (39) considers that, in young normal resting subjects breathing air at sea level, virtually all of the Aa difference is to be accounted for by venous admixture, and that this is the case during exercise not involving an $\mathrm{O}_{2}$ uptake of greater than $2,000 \mathrm{cc}$. per min. In Table VIII the percentages of venous admixture have been calculated from the Aa differences obtained in 36 normal subjects at rest and during exercise, one of whom was studied repeatedly at several different stints of work. The hemoglobin saturation of mixed venous blood was estimated by assuming that values for arterialvenous $\mathrm{O}_{2}$ difference were related to the $\mathrm{O}_{2}$ uptake in the same way as was reported by other investigators (40) for conditions at rest and during moderate exercise. For heavy exercise, the data of Asmussen and Nielsen (41) were used. It can be seen that in the group of 36 subjects the calculated per cent venous admixture declined slightly during exercise while in Subject No. 84 it remained approximately constant at five different levels of metabolic activity. The calculations suggest that it is not necessary to postulate a "membrane factor" to explain the increased Aa difference observed in normal subjects during exercise. Indeed, if one wishes to postulate a "membrane factor" during exercise, the per cent venous admixture must be assumed to be reduced below the figure obtained at rest. There is no evidence for or against the assumption that venous admixture diminishes during exercise.

It is of interest that the observed tendency of the Aa difference to increase with slight hyperventilation at rest (Table $\mathrm{V}$ ) is readily explained on the venous admixture hypothesis by a consideration of the shape of the oxyhemoglobin dissociation curve. If the per cent venous admixture and the arterio-venous oxygen difference are not greatly changed by hyperventilation, the fact that the alveolar capillary and arterial points have moved to a flatter portion of the dissociation curve necessitates an increase in the Aa difference.

It remains to consider whether or not alveolar and arterial $\mathrm{O}_{2}$ tensions can be used as sensitive criteria for the normality of pulmonary $\mathrm{O}_{2}$ transport. As seen in Table III and IV, the variability of these measurements among normal persons is greater than that of the per cent arterial hemoglobin saturation. On this basis, it would appear that arterial $\mathrm{Po}_{2}$ cannot be used to narrow the limits of normality of arterial blood oxygenation. Furthermore, the variability of the Aa difference among normal persons is of the same order as the variability of either alveolar or arterial $\mathrm{Po}_{2}$. It remains to be demonstrated that comparisons between these measurements in normal subjects and those obtained in diseased persons will prove to be of greater value as criteria for the normality of $\mathrm{O}_{2}$ transfer than the more usual determinations of arterial per cent hemoglobin saturation.

\section{SUMMARY}

1. The calculation of alveolar $\mathrm{O}_{2}$ tension from expired gas and arterial blood tension determinations provides a representative value for the $\mathrm{PO}_{2}$ to which pulmonary capillary blood is exposed in normal men breathing air at rest and during exercise if certain experimental conditions are met.

2. These conditions have been examined.

3. The mean alveolar-arterial $\mathrm{O}_{2}$ tension difference is $9.7 \mathrm{~mm}$. $\mathrm{Hg}$ (S.D. $\pm 5.3 \mathrm{~mm}$. $\mathrm{Hg}$ ) at rest and $19.6 \mathrm{~mm}$. $\mathrm{Hg}$ (S.D. $\pm 4.7 \mathrm{~mm}$. $\mathrm{Hg}$ ) during moderately strenuous exercise in normal men breathing air at 1600 feet above sea level.

4. The variability of the Aa difference in normal men at rest is not necessarily dependent on factors characteristic for each individual. This difference is significantly affected by variations in the calculated alveolar $\mathrm{Po}_{2}$, which in turn is influenced by the ratio of the minute ventilation to the $\mathrm{O}_{2}$ uptake.

5. The conditions required for calculating an alveolar $\mathrm{Po}_{2}$ are more closely approached and the $\mathrm{O}_{2}$ ventilation equivalent varies less among normal persons during exercise than at rest. For these reasons, an Aa difference measured during exercise is likely to be more characteristic for a given individual than when measured during rest.

6. The normal Aa difference during both rest and exercise can be accounted for on the hypothe- 
sis that peripheral arterial blood is normally composed of a mixture of completely oxygenated blood and of incompletely oxygenated blood which has either by-passed alveolar structures or perfused poorly ventilated alveoli.

7. The variability of the alveolar and arterial $\mathrm{O}_{2}$ tensions and of the difference between them at rest and during exercise is greater in normal subjects than is the variability of the arterial per cent hemoglobin saturation.

\section{REFERENCES}

1. Filley, G. F., Gay, E., and Wright, G. W., The accuracy of direct determinations of oxygen and carbon dioxide tensions in human blood in vitro. J. Clin. Invest., 1954, 33, 510.

2. Gréhant, N., Recherches physiques sur la respiration de l'homme. J. de l'anat. et physiol., 1864, 1, 523.

3. Fowler, W. S., Intrapulmonary distribution of inspired gas. Physiol. Rev., 1952, 32, 1.

4. Sonne, D., Modern views of the mechanism of lung function and its significance to physiology and clinical medicine. Acta med. Scandinav., 1936, 90, 315.

5. Bateman, J. B., Factors influencing the composition of alveolar air in normal persons. Proc. Staff Meet. Mayo Clin., 1945, 20, 214.

6. Bohr, C., Ueber die Lungenathmung. Skandinav. arch. f. Physiol., 1891, 2, 236.

7. Riley, R. L., and Cournand, A., "Ideal" alveolar air and the analysis of ventilation-perfusion relationships in the lungs. J. Applied Physiol., 1949, 1, 825.

8. Handbook of Respiratory Data in Aviation, Committee on Medical Research, Office of Scientific Research and Development, National Research Council, Washington, D. C., 1944.

9. Rahn, H., A concept of mean alveolar air and the ventilation-bloodflow relationships during pulmonary gas exchange. Am. J. Physiol., 1949, 158, 21.

10. Rossier, P.-H., and Blickenstorfer, E., Espace mort et hyperventilation. Helvet. med. acta, 1946, 13, 328.

11. Riley, R. L., Lilienthal, J. L., Jr., Proemmel, D. D., and Franke, R. E., On the determination of the physiologically effective pressures of oxygen and carbon dioxide in alveolar air. Am. J. Physiol., 1946, 147, 191.

12. Cournand, A., Measurement of the cardiac output in man using the right heart catheterization. Description of technique, discussion of validity and of place in the study of the circulation. Federation Proc., 1945, 4, 207.

13. Wiedel, P., and Bouchelle, McL., Unpublished data.

14. Filley, G. F., and Wright, G. W., Unpublished data.
15. Dubois, A. B., Fenn, W. O., and Britt, A. G., $\mathrm{CO}_{2}$ dissociation curve of lung tissue. J. Applied Physiol., 1952, 5, 13.

16. Krogh, A., and Krogh, M., On the tensions of gases in the arterial blood. Skandinav. arch. f. Physiol., 1910, 23, 179.

17. Dill, D. B., Hurxthal, L. M., van Caulaert, C., Fölling, A., and Bock, A. V., The carbon dioxide equilibrium in alveolar air and arterial blood. II. Resting subjects. J. Biol. Chem., 1927, 74, 313.

18. Suskind, M., Bruce, R. A., McDowell, M. E., Yu, P. N. G., and Lovejoy, F. W., Jr., Normal variations in end-tidal air and arterial blood carbon dioxide and oxygen tensions during moderate exercise. J. Applied Physiol., 1950, 3, 282.

19. Rahn, H., and Otis, A. B., Continuous analysis of alveolar gas composition during work, hyperpnea, hypercapnia and anoxia. J. Applied Physiol., 1949, $1,717$.

20. Henderson, Y., and Haggard, H. W., The circulation and its measurement. Am. J. Physiol., 1925, 73, 193.

21. Dubois, A. B., Alveolar $\mathrm{CO}_{2}$ and $\mathrm{O}_{2}$ during breathholding, expiration, and inspiration. J. Applied Physiol., 1952, 5, 1.

22. Roughton, F. J. W., Recent work on carbon dioxide transport by the blood. Physiol. Rev., 1935, 15, 241.

23. Stacy, R. W., and Kydd, G. H., III, Variation of respiratory quotient during normal and deep exhalation. Federation Proc., 1950, 9, 120.

24. Fishman, A. P., McClement, J., Himmelstein, A., and Cournand, A., Effects of acute anoxia on the circulation and respiration in patients with chronic pulmonary disease studied during the "steady state." J. Clin. Invest., 1952, 31, 770.

25. Van Slyke, D. D., and Neill, J. M., The determination of gases in blood and other solutions by vacuum extraction and manometric measurement. J. Biol. Chem., 1924, 61, 523.

26. Sendroy, J., Jr., Manometric determination of hemoglobin by the oxygen capacity method. J. Biol. Chem., 1931, 91, 307.

27. Hastings, A. B., and Sendroy, J., Jr., Studies of acidosis. XX. The colorimetric determination of blood $\mathrm{pH}$ at body temperature without buffer standards. J. Biol. Chem., 1924, 61, 695.

28. Riley, R. L., Proemmel, D. D., and Franke, R. E., A direct method for determination of oxygen and carbon dioxide tensions in blood. J. Biol. Chem., 1945, 161, 621.

29. Dill, D. B., Edwards, H. T., Fölling, A., Oberg, S. A., Pappenheimer, A. M., Jr., and Talbott, J. H., Adaptations of the organism to changes in oxygen pressure. J. Physiol., 1931, 71, 47.

30. Lilienthal, J. L., Jr., Riley, R. L., Proemmel, D. D., and Franke, R. E., An experimental analysis in man of the oxygen pressure gradient from alveolar air 
to arterial blood during rest and exercise at sea level and at altitude. Am. J. Physiol., 1946, 147, 199.

31. Comroe, J. H., Jr., and Dripps, R. D., Jr., The oxygen tension of arterial blood and alveolar air in normal human subjects. Am. J. Physiol., 1944, 142, 700.

32. Van Slyke, D. D., and Sendroy, J., Jr., Studies of gas and electrolyte equilibria in blood. XV. Line charts for graphic calculations by the Henderson-Hasselbalch equation, and for calculating plasma carbon dioxide content from whole blood content. J. Biol. Chem., 1928, 79, 781.

33. Soley, M. H., and Shock, N. W., The rate of respiratory adjustment to postural change. Am. J. Physiol., 1940, 130, 771.

34. Filley, G. F., Proemmel, D. D., and Wright, G. W., Observations regarding the interpretation of the resting calculated alveolar-arterial gradient. Symposium on Military Physiology, Digest Series No. 4, Dec., 1947, 147.

35. Bock, A. V., Dill, D. B., Edwards, H. T., Henderson, L. J., and Talbott, J. H., On the partial pres- sures of oxygen and carbon dioxide in arterial blood and alveolar air. J. Physiol., 1929, 68, 277.

36. Dill, D. B., and Penrod, K. E., Man's ceiling as determined in the altitude chamber. J. Applied Physiol., 1948, 1, 409.

37. Roughton, F. J. W., The average time spent by the blood in the human lung capillary and its relation to the rates of $\mathrm{CO}_{2}$ uptake and elimination in man. Am. J. Physiol., 1945, 143, 621.

38. Malmström, G., and Michas, P. A., Oxygen and carbon dioxide partial pressures in blood from the systemic circulation and the pulmonary capillaries. Acta med. Scandinav., 1953, 145, 91.

39. Riley, R. L., Personal communication.

40. Riley, R. L., Himmelstein, A., Motley, H. L., Weiner, H. M., and Cournand, A., Studies of the pulmonary circulation at rest and during exercise in normal individuals and in patients with chronic pulmonary disease. Am. J. Physiol., 1948, 152, 372.

41. Asmussen, E., and Nielsen, M., The cardiac output in rest and work determined simultaneously by the acetylene and dye injection methods. Acta physiol. Scandinav., 1953, 27, 217. 